\title{
The antimycotic activity of 5-fluorocytosine
}

\author{
R. J. HOLT AND THE LATE R. L. NEWMAN ${ }^{1}$ \\ From Queen Mary's Hospital for Children, Carshalton, Surrey
}

SYNOPSIS 5-Fluorocytosine (5 FC) showed marked in vitro activity against nearly all the clinical isolates of Candida and Cryptococcus examined; the required minimal inhibitory concentration was usually below $2 \mu \mathrm{g} / \mathrm{ml}$ and the minimal cidal concentration below $10 \mu \mathrm{g} / \mathrm{ml}$. The drug had limited activity towards Aspergillus species and dermatophytes. Strains of Candida and other fungi with greatly enhanced resistance were fairly readily obtained by successive cultures on increasingly high concentrations of 5-fluorocytosine.

Serum, urine, and faecal assays of 5 FC were made by a microbiological method on specimens from eight children who received between 100 and $25 \mathrm{mg} / \mathrm{kg} /$ day of the drug over several weeks for candidosis of the urinary tract usually associated with congenital anatomical abnormalities. Seven of these cases were successfully treated but in the other the Candida became highly resistant and treatment was discontinued. Serum drug levels ranged up to $30 \mu \mathrm{g} / \mathrm{ml}$; urine levels were frequently between 200 and $500 \mu \mathrm{g} / \mathrm{ml}$. No $5 \mathrm{FC}$ was detected in faecal samples.

Sensitivity tests and assays were also made on samples from subjects receiving 5 FC in other hospitals; five had systemic $C$. albicans infection, the sixth had cryptococcal meningitis. In the latter case levels up to $34 \mu \mathrm{g} / \mathrm{ml}$ were recorded in the cerebrospinal fluid after oral administration, and an investigation was made into the possibility of competitive antagonism by intrathecal cytosine arabinoside given for Hodgkin's disease. The emergence in two other cases of strains of Candida highly resistant to $5 \mathrm{FC}$ is discussed, and it is suggested that careful laboratory monitoring of cases receiving $5 \mathrm{FC}$ must continue throughout therapy and afterwards.

A serious gap has recently become increasingly apparent in our antimicrobial armoury; a wide range of drugs is now used for the safe and effective treatment of almost all bacterial disease, but only one agent, amphotericin B, has hitherto been available for systemic antimycotic therapy. The toxic hazards of this polyene are considerable and it must be used with great care. The lack of safe systemic antimycotic drugs has been emphasized after therapy with potent antibacterial and immunosuppressive agents after organ transplants, and after the use of cytotoxic drugs in leukaemia. Many of these cases ultimately suffer an overwhelming generalized mycotic infection, frequently by fungi normally regarded as feebly pathogenic or not-pathogenic. Extensive reconstructive surgery, particularly when artificial internal prostheses are implanted (Holt, 1969), carries similar risks of complication.

The emergence of new systemic antimycotic agents has therefore aroused great interest; 5fluorocytosine (5 FC) became available in the early Received for publication 28 December 1972.

${ }^{1}$ Dr Newman died after this paper had been written. 1960s when it was synthesized in the laboratories of Roche at Basel as an antimetabolite for cytosine during a search for antileukaemic drugs. In this it proved ineffective, but Grunberg, Titsworth, and Bennett (1964) showed that it was active in the control of mouse candidaemia; by the end of the decade it had been used to treat many cases of severe candidosis and cryptococcosis (Utz, Tynes, Shadomy, Duma, Kannan, and Mason, 1969; Record, Skinner, Sleight, and Speller, 1971; Davies and Reeves, 1971; and many others). The mode of action of 5-fluorocytosine has been studied extensively; at first it was suggested that the compound competed with its analogue cytosine, or with related pyrimidines, which were regarded as essential metabolites for sensitive fungal cells, but not for bacteria or mammalian cells (fig 1). Scholer (1968) suggested that sensitive fungi metabolize cytosine to uridine, and that 5 FC interferes with this process; mammalian and bacterial cells on the other hand do not metabolize cytosine in this way and 5 FC is therefore inactive towards them. In 1970 Giege and Weil showed that 5 FC may be deaminated by sensitive fungi, possibly to 


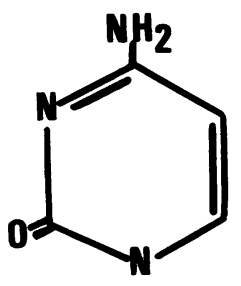

CYTOSINE

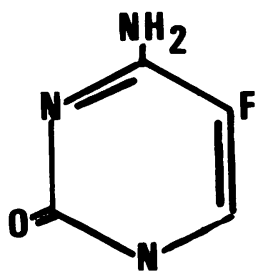

5-FLUOROCYTOSINE

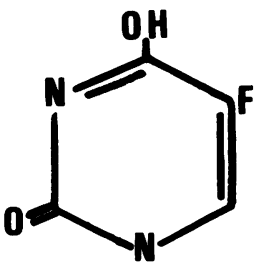

5-FLUOROURACIL

Fig. Cytosine and analogues

5-fluorouracil, which is then incorporated into their t-RNA. Up to $50 \%$ of $t-R N A$ uracil may be replaced by 5 -fluorouracil, with inhibitory effect. Whichever hypothesis is accurate, it seems certain that all experiments in vitro with 5-fluorocytosine must be performed with cytosine-free media (Shadomy, 1969); the use of standard bacteriological or mycological media containing the free amino acid invariably gives highly fallacious results in which the drug appears to be relatively inactive against fungi. Furthermore, fungi previously grown in standard media should first be subcultured in cytosine-free medium before subjecting them to sensitivity tests, so that the organisms become depleted of cytosine; washing by suspension and centrifugation in sterile buffer solution may not be sufficient. Shadomy explained the activity of $5 \mathrm{FC}$ in serum and other biological fluids by assuming that these complex mixtures of natural undegraded proteins contain no free cytosine, a suggestion that we have confirmed by chromatographic analysis.

\section{Methods}

SOLUTIONS OF 5 FC

A white, finely crystalline powder, 5 FC was dissolved at $1 \%(10000 \mu \mathrm{g} / \mathrm{ml})$ in $0.9 \%$ sterile aqueous saline at $\mathrm{pH} 6.5$; this followed the procedure of Shadomy (1969). One $\mathrm{ml}$ aliquots of this stock solution were stored at $-20^{\circ}$, where tests showed no loss of activity after six months. Appropriate dilutions were made in $0.01 \mathrm{M}$ phosphate buffer at pH 7.0.

\section{CLINICAL ISOLATES}

Candida and fungi were isolated from clinical specimens by the methods reported elsewhere (Holt and Newman, 1967). Czapek Dox agar or Sabouraud glucose peptone agar, incorporating $100 \mu \mathrm{g} / \mathrm{ml}$ gentamicin, were used for the recovery of fungi from specimens heavily contaminated with bacteria. Every effort was made to perform sensitivity tests as soon as possible after primary isolation.

Candida isolates were routinely differentiated into Candida albicans and non-albicans by the serum germ tube and chlamydospore formation tests. Speciation of candida strains and of systemic fungi was carried out at the Mycology Reference Laboratory, London, by the kindness of the late Dr I. G. Murray and more recently Miss C. Philpott; this laboratory and that of Dr Y. Clayton also kindly supplied many fungi of medical interest for sensitivity tests.

\section{MEDIA}

Shadomy (1969) recommended the use of yeast nitrogen base supplemented with L-asparagine and dextrose, according to the formulae of Wickerham; concentrated media for all tests described in the present study were therefore prepared by dissolving 6.7 g Bacto-yeast nitrogen base (code 0392), $1.5 \mathrm{~g}$ $\mathrm{L}$-asparagine, and $10.0 \mathrm{~g}$ dextrose in $100 \mathrm{ml}$ glassdistilled water. The solution was sterilized by membrane filtration, and was a $10 \times$ concentrate, 1 volume of which was diluted with 9 volumes of sterile fluid for use. For liquid tests $0.01 \mathrm{M}$ phosphate

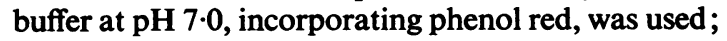
sterile $1 \%$ ion agar (Oxoid L 12) in distilled water, molten, and cooled to $45^{\circ}$, was used as diluent for all plate tests. Chromatography showed no free cytosine present in either yeast nitrogen base or ion agar.

When tests were made with clinical specimens which were possibly contaminated with bacteria, 100 $\mu \mathrm{g} / \mathrm{ml}$ of gentamicin base was included. A series of experiments demonstrated that this antibiotic concentration in no way affected the activity of $5 \mathrm{FC}$ in yeast nitrogen base broth or agar.

\section{SENSITIVITY TESTS}

By discs containing 1,10 , and $100 \mu g 5$ FC

Filter paper discs, $9 \mathrm{~mm}$, were impregnated with $5 \mathrm{FC}$ solution and rapidly vacuum dried. The discs were presterilized in dry air at $160^{\circ}$ for one $\mathrm{hr}$; dilutions of $5 \mathrm{FC}$ were made in $0.01 \mathrm{M}$ phosphate buffer at pH $7 \cdot 2$ to contain 30,300 , and $3000 \mu \mathrm{g} / \mathrm{ml}$. Discs of the required strength were prepared by placing one drop from a 30 drop/ml pipette onto the appropriate paper, which was immediately vacuum dried at room temperature over silica gel. The dry discs were 
stored in tightly capped containers at $4^{\circ}$, under which condition no deterioration was revealed by assays three months later.

The fungus to be tested was grown overnight in yeast nitrogen base broth; in this and all other subculture prodecures used in these studies every care was taken when removing fungi from normal culture media presumed to contain free cytosine to ensure that a minimum of the medium was carried over into cytosine-free cultures. The overnight yeast nitrogen base broth culture was diluted in yeast nitrogen base broth containing $0.1 \%$ of a nonionic surfactant (Triton X100) to a density of approximately $1 \times 10^{5}$ cells per ml for candida or cryptococci; this was impossible with mycelating fungi, so $1 / 100$ dilutions of very well mixed overnight cultures were made. An even lawn of dilute suspension was sown over yeast nitrogen base agar or Czapek Dox plates and allowed to dry for one hour. Dises containing the three concentrations of 5 FC were placed on the agar surface and the plates incubated for 48 hours. Organisms giving zones of inhibition greater than $20 \mathrm{~mm}$ diameter round the $1 \mu \mathrm{g}$ discs were recorded as fully sensitive; zones between 14 and $18 \mathrm{~mm}$ diameter round the $10 \mu \mathrm{g}$ disc were regarded as resistant to the drug.

Because of our interest in the emergence of strains relatively resistant to $5 \mathrm{FC}$, all sensitivity plates were carefully scrutinized for a minority of colonies growing in the zone of inhibition near the disc; most plates were therefore kept for four to five days before being discarded.

By liquid tests: the estimation of minimal inhibitory and cidal concentrations (MIC and MCC)

All estimations and assays were carried out at $\mathbf{p H}$ 7.0 and at $37^{\circ}$ to simulate biological conditions. Concentrations of $5 \mathrm{FC}$ in the range $0.05-50 \mu \mathrm{g} / \mathrm{ml}$ were made in $2 \mathrm{ml}$ tubes of yeast nitrogen base broth together with a broth tube without drug. Inocula of Candida and other yeast-like organisms were added to give a final initial concentration of about $1 \times 10^{5}$ cells $/ \mathrm{ml}$; mycelating fungi were added as a very light inoculum. All cultures were thoroughly mixed and incubated for $48 \mathrm{hr}$, after which the MIC was noted by visible turbidity. Standard loop subcultures from each tube were made onto standard infusion broth agar plates, which were incubated for 24 to 48 $\mathrm{hr}$ and the MCC recorded by visible growth. This medium contained cytosine, which effectively antagonizes the antimycotic action of $5 \mathrm{FC}$, thus fulfilling one of the desirable conditions for the test because it is possible to neutralize the inhibitory action of the drug carried over from the first stage. With many antimicrobial agents it is difficult to meet this requirement.
The agar dilution technique was also used to estimate sensitivity to $5 \mathrm{FC}$; light inocula of fungi were spotted onto yeast nitrogen base agar plates containing a range of drug concentrations; the MIC was read after 48 hours' incubation and the MCC by subsequent velvet pad replication onto drug-free infusion agar. Results from liquid tests compared well with the agar dilution readings.

\section{Induction of Resistant Mutants}

Very light inocula of fungi were successively passaged across increasing drug gradients on yeast nitrogen base agar plates (Szybalski, 1952), usually starting with plates having a gradient $0.02 \mu \mathrm{g} / \mathrm{ml} 5$ FC. Each series of plates was given 48-72 hours' incubation for a sequence of 20 passages, and the initial liquid MIC of each strain was compared with the final liquid MIC.

\section{Assay of 5 FC in Biological Fluids}

Shadomy (1969) used a saccharomyces sp. (S. cerevisiae ATCC 9763) as indicator organism in plate bioassays, and found the lower limit of sensitivity of his method to be about $0.4 \mu \mathrm{g} / \mathrm{ml}$. We tested this strain and many other strains of Saccharomyces and Candida, and eventually selected a strain of C. albicans (Carshalton 2606) for routine assays; this readily detected $0.1 \mu \mathrm{g} / \mathrm{ml} 5 \mathrm{FC}$. The indicator organism used by us for clotrimazole assays, $C$. pseudotropicalis Carshalton, had a similar level of sensitivity to 5 FC.

The assay strain was maintained in yeast nitrogen base broth by daily subcultures and on each occasion a plate-out was included to check purity. Base layers of $50 \mathrm{ml}$ of $1 \%$ ion agar were poured into $14 \mathrm{~cm}$ polystyrene plates and after setting they were overlaid with $20 \mathrm{ml}$ of yeast-nitrogen base agar seeded with $0.1 \mathrm{ml}$ of overnight indicator-organism culture; the plates were thoroughly dried at $37^{\circ}$. Larger square assay plates, $25 \times 25 \mathrm{~cm}$, were also used, with $200 \mathrm{ml}$ base and $80 \mathrm{ml}$ overlay.

The range of standards was $0 \cdot 1,0 \cdot 5,2 \cdot 0$, and 10 $\mu \mathrm{g} / \mathrm{ml} 5 \mathrm{FC}$ prepared in $0.01 \mathrm{M}$ buffer at $\mathrm{pH} 7.0$. Earlier studies had confirmed the observation of Davies and Reeves (1971) that zone diameters for 5 FC in serum were the same as those in aqueous solution, and the latter were therefore used for bioassays of all biological fluids. These were diluted in buffer to final levels of $5 \mathrm{FC}$ within the standard range; sera were diluted $1 / 5$ or $1 / 10$, and urines usually $1 / 100$.

Diluted fluids and standards were applied to the agar surface in fish-spine bead reservoirs (Lightbown and Sulitzeau, 1957), and plates incubated for $24 \mathrm{hr}$ 
at $37^{\circ}$ on a level surface after prediffusion for two $\mathrm{hr}$ at room temperature. Standard curves were constructed on half-log paper and the concentration of 5 FC in each fluid was estimated.

\section{Clinical Experience}

\section{CRITERIA FOR TREATMENT OF CHILDREN IN} THIS HOSPITAL

Therapy with 5 FC was started only after several urine specimens from each patient were found to contain numerous pus cells and high candida counts; every effort was made to obtain very fresh specimens before regarding the diagnosis as established. Suprapubic aspiration of urine was not attempted because, as will be seen in table IV, many of the children in this series had gross anatomical abnormalities of the urinary tract.

\section{CRITERIA OF SUCCESSFUL THERAPY}

Fresh specimens of urine were examined at least once a day throughout treatment and for several weeks after the drug was stopped. General clinical improvement, complete absence of viable Candida, and marked diminution of the pus cell count in several successive specimens were required before therapy was stopped. Assessment of complicated cases such as these is notoriously difficult, and bacterial infection sometimes obscured the picture.

\section{ADMINISTRATION OF DRUG}

On most occasions adults received tablets containing $0.5 \mathrm{~g} 5 \mathrm{FC}$ at six or eight hourly intervals to a total of $100 \mathrm{mg} / \mathrm{kg} / \mathrm{day}$. The tablets were unsuitable for infants, who were given an aqueous suspension of crushed tablets containing the calculated six hourly dose in 1 or $2 \mathrm{ml}$. Gum tragacanth $(0.2 \%)$ was added to the suspension, which was stored at $4^{\circ} \mathrm{C}$; assays revealed that it remained stable for three months under these conditions, although no more than 14 days' supply was issued at a time to the wards.

\section{DOSAGE}

Our first cases were given $100 \mathrm{mg} / \mathrm{kg} /$ day $5 \mathrm{FC}$ as an oral suspension in four six-hourly doses per day. It was soon found that serum levels over $20 \mu \mathrm{g} / \mathrm{ml}$ and urine levels well above $200 \mu \mathrm{g} / \mathrm{ml}$ resulted from this dose; in later cases, therefore, the dose was successively reduced after about a week to $50 \mathrm{mg} / \mathrm{kg} /$ day and then to $25 \mathrm{mg} / \mathrm{kg} /$ day for the remainder of the course, providing that assays revealed satisfactory levels. None of our patients showed any side effects attributable to the drug.

FAECAL ASSAYS

Aqueous extracts from 10 samples of faeces from four of the infants receiving 5 FC were assayed. No FC was detected in any. Chromatographic analysis of two of these extracts revealed so confused a picture that it was impossible to say whether free cytosine was present.

\section{PATIENTS IN OTHER HOSPITALS}

In addition to the eight children reported above, sensitivity tests and some assays were performed on specimens from subjects receiving $5 \mathrm{FC}$ in other hospitals. In most cases the dose was close to 100 $\mathrm{mg} / \mathrm{kg} /$ day, although for a few days two patients received approximately $200 \mathrm{mg} / \mathrm{kg} /$ day, later reduced to $100 \mathrm{mg} / \mathrm{kg} /$ day or less.

\section{Results}

EFFECT OF CYTOSINE ARABINOSIDE ON THE ACTIVITY OF 5 FC TOWARDS CRYPTOCOCCUS NEOFORMANS

The patient with cryptococcal meningitis was also receiving intrathecal cytosine arabinoside for Hodgkin's disease with meningeal involvement. It seemed important to establish whether this cytosine derivative antagonized the action of 5 FC to the same degree as cytosine. Titrations of both were set up in yeast nitrogen base broth, with a light inoculum of the patient's own strain of Cr. neoformans, to give an initial concentration of $1 \times 10^{5}$ cells per $\mathrm{ml}$. Results were read after $48 \mathrm{hr}$ at $37^{\circ}$. Concentrations of cytosine arabinoside between $1 \mu \mathrm{g} / \mathrm{ml}$ and 10 $\mu \mathrm{g} / \mathrm{ml}$ were used because it was estimated that the body fluid concentrations of this compound would probably be in that range.

Cytosine arabinoside alone up to $100 \mu \mathrm{g} / \mathrm{ml}$ was found to have no inhibitory action on the $\mathrm{Cr}$. neoformans. At a concentration of $1 \mu \mathrm{g} / \mathrm{ml}$ both cytosine and cytosine arabinoside reduced the activity of $5 \mathrm{FC}$ at least one hundredfold. There appeared to be no such interference by procarbazine (Natulan, Roche) at concentrations up to $20 \mu \mathrm{g} / \mathrm{ml}$ in a similar experiment, and the patient later received this drug.

\section{Discussion}

The activity in vitro of 5-fluorocytosine is confined largely to yeast-like genera, principally Candida and Cryptococcus, and we confirm the observations of Shadomy (1969) that the drug has only limited activity against Aspergillus spp (table I). In the case of Candida, fungistatic and fungicidal concentrations were almost always in the range of 0.2 to $2 \mu \mathrm{g} / \mathrm{ml}$ and 2 to $50 \mu \mathrm{g} / \mathrm{ml}$ respectively, and corresponding values of 0.2 to $2 \mu \mathrm{g} / \mathrm{ml}$ and 0.2 to $10 \mu \mathrm{g} / \mathrm{ml}$ were found for a few fresh clinical isolates of $\mathrm{Cr}$. neoformans (table II). A small proportion of Candida species 


\begin{tabular}{|c|c|c|c|c|c|c|}
\hline \multirow[t]{2}{*}{ Species } & \multirow[t]{2}{*}{ Number Tested } & & \multicolumn{4}{|c|}{ Concentration of $5 F C(\mu \mathrm{g} / \mathrm{ml})$} \\
\hline & & & 10 & $10-50$ & $50-200$ & 200 \\
\hline Aspergillus fumigatus & 10 & $\begin{array}{l}\text { MIC } \\
\text { MCC }\end{array}$ & - & 1 & 4 & $\begin{array}{c}5 \\
10\end{array}$ \\
\hline Aspergillus favus & 3 & $\begin{array}{l}\text { MIC } \\
\text { MCC }\end{array}$ & - & 1 & $\begin{array}{l}2 \\
1\end{array}$ & $\overline{2}$ \\
\hline Aspergillus niger & 3 & $\begin{array}{l}\text { MIC } \\
\text { MCC }\end{array}$ & - & - & 3 & $\frac{-}{3}$ \\
\hline
\end{tabular}

Table I Sensitivity of Aspergillus spp to 5 FC

\begin{tabular}{|c|c|c|c|c|c|c|c|}
\hline \multirow[t]{2}{*}{ Species } & \multirow[t]{2}{*}{ No. Tested } & & \multicolumn{5}{|c|}{ Concentration of $5 \mathrm{FC}(\mu \mathrm{g} / \mathrm{ml})$} \\
\hline & & & $<0 \cdot 2$ & $0 \cdot 2-2$ & $2-10$ & $10-50$ & $>50$ \\
\hline \multirow[t]{2}{*}{ Candida albicans } & 64 & MIC & 22 & 39 & 3 & - & - \\
\hline & & MCC & 2 & 4 & 28 & 26 & 4 \\
\hline \multirow[t]{2}{*}{ Candida non-albicans } & 19 & MIC & 12 & 6 & 1 & - & - \\
\hline & & MCC & - & 4 & 12 & 3 & - \\
\hline \multirow{2}{*}{ Cryptococcus neoformans } & 4 & MIC & 4 & 2 & - & - & - \\
\hline & & MCC & 1 & 2 & 3 & - & - \\
\hline \multirow{2}{*}{ Torulopsis glabrata } & 3 & MIC & - & 3 & - & - & - \\
\hline & & MCC & - & - & 3 & - & - \\
\hline \multirow[t]{2}{*}{ Geotrichum candidum } & 2 & MIC & 1 & 1 & - & 一 & - \\
\hline & & MCC & - & 1 & 1 & - & - \\
\hline
\end{tabular}

Table II Sensitivity of Candida, Cryptococcus neoformans, Torulopsis, and Geotrichum to 5 FC

recovered from clinical sources where the drug had never been used required fungicidal concentrations well above $50 \mu \mathrm{g} / \mathrm{ml}$, probably up to $500-1000 \mu \mathrm{g} / \mathrm{ml}$, and we agree with Shadomy that these must be regarded as natural occurrences. The important practical consequence is that all strains recovered from patients should be tested for sensitivity to the drug, both before and during treatment. Furthermore, we believe that sensitivity tests should be made in liquid medium to reveal the presence of a minority population of fungal cells with greater resistance to 5 FC than the remainder (Holt and Newman, 1972a), and that it may often be a mistake to regard a culture as homogenous in its drug sensitivity.

The serum and urine $5 \mathrm{FC}$ levels in all the patients reported here exceeded the fungal MIC/MCC values at the beginning of treatment (table III). The first cerebrospinal fluid level $(34 \mu \mathrm{g} / \mathrm{ml})$ in the patient with cryptococcal meningitis was very much the same as his serum level $(26 \mu \mathrm{g} / \mathrm{ml})$, both taken some five hours after an oral dose of $1.5 \mathrm{~g}$ (table IV). This suggests that the small molecule diffuses easily through body barriers and that therapeutic levels would be found in sputa of patients receiving the drug for pulmonary mycoses; no such specimens have yet passed through our hands. The second cerebrospinal fluid level was much lower and coincided with the intrathecal use of cytosine arabinoside; tests in vitro clearly showed that this agent antagonized the inhibitory action of 5 FC against the patient's strain of Cr. neoformans, probably acting in the same way as cytosine.
We were unable to record a coherent series of serum assays to demonstrate peak levels after an oral dose; the adult patients in other hospitals were not accessible to us and the small infants in this hospital were too sick for frequent blood sampling. Our impression is that the peak serum level occurred between one and two hours after a dose, and we tried wherever possible to sample blood at two and six hours. The faeces assayed were all from infants; failure to demonstrate active antimycotic activity in any may have been due to one or more of several causes: technical inadequacy of the extraction process, total absorption of the drug, destruction or conjugation to inactive derivatives are all possible reasons.

A clear warning was sounded by Shadomy (1969) when he noted that resistant strains of Candida and Cryptococci occasionally emerged during therapy, an observation reinforced in our minds when we found that members of these genera could readily be trained in vitro to very high levels of 5 FC resistance (table V). From the start of our therapeutic studies with the drug a careful watch was therefore kept both for infecting fungi with a minority population of greater resistance than the majority and for emergent resistant strains. For a long time none was seen, but during the past few months we have investigated three instances. In the first, reported by Cartwright, Shaldon, and Hall (1972), the sensitivity of $C$. albicans in the urine of a man receiving 5 FC for urinary candidosis after renal transplantation escalated from $0.25 \mu \mathrm{g} / \mathrm{ml}$ to more than $1000 \mu \mathrm{g} / \mathrm{ml}$ 


\begin{tabular}{|c|c|c|c|c|c|c|c|c|c|c|}
\hline \multirow[t]{2}{*}{ No. } & \multirow[t]{2}{*}{ Sex } & \multirow[t]{2}{*}{ Age } & \multirow[t]{2}{*}{$\begin{array}{l}\text { Weight } \\
(k g)\end{array}$} & \multirow[t]{2}{*}{ Clinical Details } & \multicolumn{2}{|c|}{$\begin{array}{l}\text { Sensitivity to } \\
5 \mathrm{FC}(\mu \mathrm{g} / \mathrm{ml})\end{array}$} & \multirow{2}{*}{$\begin{array}{l}\text { Duration } \\
\text { of Therapy } \\
\text { (days) }\end{array}$} & \multicolumn{2}{|c|}{$\begin{array}{l}\text { Range of assay } \\
\text { Results }(\mu g / m l)\end{array}$} & \multirow[t]{2}{*}{ Outcome } \\
\hline & & & & & $M I C$ & $M C C$ & & Serum & Urine & \\
\hline 1 & $\mathbf{M}$ & $(1 / 12)$ & 3 & $\begin{array}{l}\text { Left nephro-ureter- } \\
\text { ectomy, transurethral } \\
\text { resection of valves; } \\
\text { C. albicans in urine }\end{array}$ & $0 \cdot 1$ & 2 & 21 then 16 & $\begin{array}{l}14-25 \\
(12 \text { tested })\end{array}$ & $\begin{array}{l}80-200 \\
(23 \text { tested) }\end{array}$ & $\begin{array}{l}\text { Clotrimazole had pre- } \\
\text { viously failed. Urine } \\
\text { cultures negative after } 5 \text { th } \\
\text { day but Candida reappeared } \\
\text { after end of first course. } \\
\text { No recurrence. }\end{array}$ \\
\hline 2 & $\mathbf{F}$ & $1(4 / 12)$ & 8 & $\begin{array}{l}\text { Meningomyelocele and } \\
\text { hydrocephalus, hydro- } \\
\text { nephrosis, ileal loop } \\
\text { constructed; } C \text {. pseudo- } \\
\text { tropicalis in urine }\end{array}$ & $0 \cdot 2$ & 1 & 31 & $\begin{array}{l}0.9-13 \\
(19)\end{array}$ & $\begin{array}{l}130-500 \\
(21)\end{array}$ & $\begin{array}{l}\text { Cultures negative after } \\
\text { first } 24 \mathrm{hr} \text {. No recurrence. }\end{array}$ \\
\hline 3 & $\mathbf{F}$ & $2(8 / 12)$ & 16 & $\begin{array}{l}\text { Meningomyelocele and } \\
\text { hydrocephalus; dilatation, } \\
\text { upper urinary tract; ileal } \\
\text { loop; } C \text {. albicans in urine }\end{array}$ & $0 \cdot 1$ & 0.5 & 16 & $\begin{array}{c}7 \\
(1)\end{array}$ & $\begin{array}{l}80 \& 600 \\
(2)\end{array}$ & $\begin{array}{l}\text { Cultures negative after } 5 \\
\text { days. No recurrence. }\end{array}$ \\
\hline 4 & $\mathbf{M}$ & $(2 / 12)$ & 4 & $\begin{array}{l}\text { Nephrostomies, ureteric } \\
\text { implants, unhealed } \\
\text { suprapubic catheter track; } \\
\text { C. albicans in urine }\end{array}$ & $0 \cdot 1$ & 0.5 & 77 & $\begin{array}{l}7-22 \\
(8)\end{array}$ & $\begin{array}{l}16-500 \\
(48)\end{array}$ & $\begin{array}{l}\text { Cultures negative after } 7 \\
\text { days. Negative till } 77 \text { days, } \\
\text { then scanty Candida, with } \\
\text { greatly increased MCC; } \\
\text { persisted. }\end{array}$ \\
\hline 5 & $\mathbf{M}$ & $(3 / 12)$ & 3 & $\begin{array}{l}\text { Urethral valves, trans- } \\
\text { urethral resection; } \\
\text { C. albicans in urine }\end{array}$ & $0 \cdot 2$ & $1-2$ & 48 & $\begin{array}{l}8-21 \\
(3)\end{array}$ & $\begin{array}{l}30-500 \\
(7)\end{array}$ & $\begin{array}{l}\text { Cultures negative after } 7 \\
\text { days. Remained so. No } \\
\text { recurrence. }\end{array}$ \\
\hline 6 & $\mathbf{M}$ & $(5 / 12)$ & 7 & $\begin{array}{l}\text { Meningomyelocele and } \\
\text { hydrocephalus, left ureteric } \\
\text { reflux; systemic gentamicin } \\
\text { for Gram-positive } \\
\text { septicaemia; } C \text {. albicans } \\
\text { repeatedly in urine }\end{array}$ & 0.5 & $2-5$ & 42 & $\begin{array}{l}14-24 \\
(4)\end{array}$ & $\begin{array}{l}150-280 \\
(6)\end{array}$ & $\begin{array}{l}\text { Cultures negative after } 4 \\
\text { days; remained so. No } \\
\text { recurrence }\end{array}$ \\
\hline 7 & $\mathbf{M}$ & $(2 / 12)$ & 4 & $\begin{array}{l}\text { Urethral valves; bilateral } \\
\text { nephrostomy; dilatation } \\
\text { of valves; } C \text {. albicans } \\
\text { repeatedly in urine }\end{array}$ & $0 \cdot 1$ & 0.5 & 40 & $\begin{array}{l}8-30 \\
(6)\end{array}$ & $\begin{array}{l}120-600 \\
(12)\end{array}$ & $\begin{array}{l}\text { Cultures negative after } 8 \\
\text { days; remained so. No } \\
\text { recurrence }\end{array}$ \\
\hline 8 & $\mathbf{M}$ & $(6 / 12)$ & 7 & $\begin{array}{l}\text { Bilateral nephrostomies, } \\
\text { ileal loop; C. albicans } \\
\text { from loop urines and } \\
\text { catheter urines }\end{array}$ & $0 \cdot 1-0 \cdot 2$ & 0.5 & 23 & $\begin{array}{l}14-20 \\
(2)\end{array}$ & $\begin{array}{l}280-800 \\
(5)\end{array}$ & $\begin{array}{l}\text { Cultures negative after } 10 \\
\text { days; remained negative } \\
\text { for } 30 \text { days. }\end{array}$ \\
\hline
\end{tabular}

Table III Children treated with 5-fluorocytosine

\begin{tabular}{|c|c|c|c|c|c|c|c|c|c|}
\hline \multirow[t]{3}{*}{ No. } & \multirow[t]{3}{*}{ Case Description } & \multirow[t]{3}{*}{ Age } & \multirow{2}{*}{\multicolumn{2}{|c|}{$\begin{array}{l}\text { Sensitivity to } 5 F C \\
(\mu \mathrm{g} / \mathrm{ml})\end{array}$}} & \multirow{3}{*}{$\begin{array}{l}5 \text { FC Dose } \\
\text { (mg/kg/dav) }\end{array}$} & \multicolumn{3}{|c|}{$5 F C$ Assays } & \multirow[t]{3}{*}{ Comment } \\
\hline & & & & & & $C S F$ & Serum & Urine & \\
\hline & & & $M I C$ & $M C C$ & & & & & \\
\hline 1 & $\begin{array}{l}\text { Cryptococcal meningitis } \\
\text { Hodgkin's disease }\end{array}$ & 32 & 0.01 & $0.01-0.02$ & $\begin{array}{l}200 \text { then } 100 \\
\text { after } 3 \text { days }\end{array}$ & \multirow[t]{5}{*}{$\begin{array}{l}34 \\
3 \cdot 5\end{array}$} & $\begin{array}{l}66,26 \\
3 \cdot 5\end{array}$ & $\begin{array}{l}2000 \\
1000 \\
2000\end{array}$ & \multirow[t]{5}{*}{$\begin{array}{l}\text { High CSF level before } \\
\text { cytosine arabinoside } \\
\text { given }\end{array}$} \\
\hline 2 & C. albicans endocarditis & 44 & $0 \cdot 2-0 \cdot 5$ & 2 & $\begin{array}{l}200, \text { later } \\
70\end{array}$ & & $\begin{array}{l}26,28,12 \\
22,9 \cdot 5,7\end{array}$ & $\begin{array}{l}55,50,18 \\
300,300 \\
300\end{array}$ & \\
\hline 3 & C. albicans endocarditis & 67 & $0 \cdot 8$ & $5-10$ & 100 & & $\begin{array}{l}14,27,22 \\
30\end{array}$ & $\begin{array}{l}50,120 \\
70,75\end{array}$ & \\
\hline 4 & $\begin{array}{l}\text { Renal transplant, } \\
\text { C. albicans urinary tract }\end{array}$ & 42 & $0 \cdot 05-0 \cdot 1$ & $1-2$ & & & & & \\
\hline 5 & $\begin{array}{l}\text { Urogenital surgery } \\
\text { C. albicans urinary tract } \\
\text { infection }\end{array}$ & 5 & $0 \cdot 1-0 \cdot 2$ & $5-10$ & & & & & \\
\hline
\end{tabular}

Table IV Details of patients who received 5-fluorocytosine in other hospitals

during six days' treatment. The cultures were kindly referred to us at an early stage, and our impression was that the pretreatment culture contained a minority population of 5 FC-resistant cells, which rapidly emerged despite adequate urine and serum drug levels; in our hands both sensitive and resistant isolates were sensitive to clotrimazole, with which this patient was successfully treated. The second case was no. 4 in our series, where the strain of C. albicans was initially homogenous and fully sensitive to $5 \mathrm{FC}$ (MIC $0.05 \mu \mathrm{g} / \mathrm{ml}$, MCC $1 \mu \mathrm{g} / \mathrm{ml}$ ). After 20 weeks' treatment, during which high serum and urine drug levels were maintained, $C$. albicans reappeared in the urine, apparently identical to the pretreatment 8 


\begin{tabular}{|c|c|c|c|c|}
\hline \multirow[t]{2}{*}{ Strain No. } & \multirow[t]{2}{*}{ Species } & \multirow{2}{*}{ Number of Passages } & \multicolumn{2}{|c|}{$M I C / M C C$ in Liquid Medium $(\mu g / m l)$} \\
\hline & & & Before Passage & After Passage \\
\hline $\begin{array}{l}1 \\
2 \\
3 \\
4 \\
5 \\
6 \\
7 \\
8\end{array}$ & $\begin{array}{l}\text { C. albicans } \\
\text { C. albicans } \\
\text { C. albicans } \\
\text { C. albicans } \\
\text { C. pseudotropicalis } \\
\text { C. non-albicans } \\
\text { C. non-albicans } \\
\text { Cryptococcus neoformans }\end{array}$ & $\begin{array}{l}15 \\
10 \\
10 \\
12 \\
15 \\
15 \\
10 \\
15 \\
15\end{array}$ & $\begin{array}{l}0 \cdot 1 / 2 \cdot 0 \\
1 / 10 \\
2 / 10 \\
1 / 20 \\
0.1 / 1 \\
0.2 / 2 \cdot 0 \\
5 / 20 \\
1 / 2 \\
0.5 / 5\end{array}$ & $\begin{array}{c}2 \cdot 0 / 50 \\
100 />500 \\
100 />500 \\
>500 />500 \\
2 / 10 \\
10 / 50 \\
>500 />500 \\
10 / 100 \\
20 / 100\end{array}$ \\
\hline
\end{tabular}

Table V Changes in sensitivity to 5 FC after passage on gradient plates ${ }^{1}$

'Strains nos. 2, 5, and 8 were stored in YNB agar stab after the series of passages; after 12 weeks no changes in the enhanced MIC/MCC were noted.

isolates, save that the MIC and MCC were now over $500 \mu \mathrm{g} / \mathrm{ml}$. Both isolates were moderately sensitive to clotrimazole, which successfully eliminated the infection. The third case, referred to us by Dr Logan, was a man with $C$. albicans endocarditis, for which amphotericin B was first given for one month but was discontinued because of thrombocytopenia and anaemia. Blood cultures still grew $C$. albicans, apparently homogenous and fully sensitive to $5 \mathrm{FC}$, which was therefore given. Within a few weeks no Candida was isolated from the blood, which contained high levels of the drug, and the Candida serum antibody level was markedly reduced. The drug was continued for six months at $200 \mathrm{mg} / \mathrm{kg} /$ day with a view to eventual aortic valve replacement, but the man then relapsed; $C$. albicans was isolated from his blood and throat. We found the isolate to be totally resistant to 5 FC (MIC and MCC above 1000 $\mu \mathrm{g} / \mathrm{ml}$ ) but sensitive to clotrimazole; he was given this for 10 days but then died suddenly after rupture of an aortic valve cusp (Logan and Goldberg, 1972). C. albicans was isolated from vegetations on the aortic valve; it is impossible now to ascertain whether the final infection was caused by an entirely different strain of $C$. albicans.

5-Fluorocytosine must be viewed against the limited range of systemic antimycotic agents now available; amphotericin $B$ is frequently toxic and many clinicians, particularly paediatricians, are reluctant to use it. Imidazole derivatives, which share with 5 FC the valuable property of establishing active body fluid levels from oral absorption, have not been administered systemically or intrathecally until very recently and little is known of their efficacy or hazards by these routes. They have, however, a much wider antifungal range than 5 FC (Holt, 1970; Holt and Newman, 1972b) and an almost infinite range of derivatives is possible, with widely differing pharmacological properties. Although recent experiences with $5 \mathrm{FC}$ have naturally led us to temper our earlier optimism, its success in seven of our eight cases leaves us with little doubt of its potential. Providing searching studies in vitro are continued for emergent resistance in each subject treated, the drug will take a valuable share in meeting the ever-increasing demand for systemic antimycotic agents.

We are grateful to $\mathrm{Mr}$ H. B. Eckstein and Mr D. M. Forrest, consultant surgeons to this hospital, for permission to treat children in their care and to the staff on their wards for unfailing cooperation. The help of the staff in our routine microbiology laboratories and, at different times, of Mrs G. Thompson, FIMLT, Mr D. Manson-Smith, FIMLT, and Mrs S. Graham, FIMLT, is deeply appreciated. Dr D. G. Wells, Dr R. Cartwright, and Dr R. L. Logan and many clinicians in other hospitals kindly sent us specimens from their cases, and to all of these we are greatly indebted. 5-Fluorocytosine in a variety of presentations was supplied by Roche Products Ltd, of Welwyn Garden City, Herts.

\section{References}

Cartwright, R. Y., Shaldon, C., and Hall, G. H. (1972). Urinary candidiasis after renal transplantation. Brit. med. J., 2, 351.

Davies, R. R., and Reeves, D. S. (1971). 5-Fluorocytosine and urinary candidiasis. Brit. med. J., 1, 577-579.

Giege, R., and Weil, J. H. (1970). Des tRNA de levure ayant incorporé du 5-fluorouracill provenant de la désamination in vivo de la 5-fluorocytosine. Bull. Soc. Chim. biol. (Paris), 52, $135-144$.

Grunberg, E., Titsworth, E., and Bennett, M. (1964). Chemotherapeutic activity of 5-Fluorocytosine. Antimicrob. Agents Chemother., 3, (1963), 566-568.

Holt, R. J. (1969). The classification of staphylococci from colonized ventriculo-atrial shunts. J. clin. Path., 22, 475-482.

Holt, R. J. (1970). Studies on the broad-spectrum antimycotic agent Bay b5097, Clotrimazole. In Proceedings of the 10th International Congress of Microbiology (Mexico City), p. 149.

Holt, R. J., and Newman, R. L. (1967). Candida in the faeces of children receiving oral tetracycline and phenoxymethyl penicillin. J. clin. Path., 20, 80-83.

Holt, R. J., and Newman, R. L. (1972a). Urinary candidiasis after renal transplantation. Brit. med. J., 2, 714-715.

Holt, R. J., and Newman, R. L. (1972b). Laboratory assessment of the antimycotic drug clotrimazole. J. clin. Path., 25, 1089-1097. 
Lightbown, J. W., and Sulitzeanu, D. (1957). The assay of penicillin in blood serum using Sarcina lutea. Bull. Wld Hlth Org., 17, 553-567.

Logan, R. L., and Goldberg, M. J. (1972). C. albicans resistance to 5-fluorocytosine. Brit. med. J., 3, 531.

Record, C. O., Skinner, J. M., Sleight, P., and Speller, D. C. E. (1971). Candida endocarditis treated with 5-fluorocytosine. Brit. med. J., 1, 262-264.

Scholer, H. J. (1968). Chemotherapie von Mykosen der inneren
Organe. Schineiz. med. Wschr., 98, 602-611.

Shadomy, S. (1969). In vitro studies with 5-fluorocytosine. Appl. Microbiol., 17, 871-877.

Szybalski. W. (1952). Gradient plate technique for study of bacterial resistance. Science, 116, 46-48.

Utz, J. P., Tynes, B. S., Shadomy, H. J., Duma, R. J., Kannan, M. M., and Mason, K. N. (1969). 5-fluorocytosine in human cryptococcosis. Antimicrob. Agents Chemother., 8 (1968), 344346. 